\title{
Land-Use Legacies and Vegetation Recovery 90 Years After Cultivation in Great Basin Sagebrush Ecosystems
}

\author{
L. R. Morris, ${ }^{1}$ T. A. Monaco, ${ }^{2}$ and R. L. Sheley ${ }^{3}$ \\ Authors are ${ }^{1}$ Postdoctoral Research Associate and ${ }^{2}$ Ecologist, US Department of Agriculture, Agricultural Research Service, Forage and Range Research \\ Laboratory, Utah State University, Logan, UT 84322-6300, USA; and ${ }^{3}$ Ecologist, US Department of Agriculture, Agricultural Research Service, Range \\ and Forage Meadow Management Unit, Burns, OR 97720, USA.
}

\begin{abstract}
Agricultural land use is known to alter ecological processes, and native plant communities can require decades to centuries to recover from the disturbance of cultivation. "Recovery" is typically measured by comparison to undisturbed adjacent sites as a control. Recovery following cultivation in sagebrush ecosystems of the Great Basin remains largely unexamined even though nearly a half million hectares of land were dry-farmed and abandoned in the early 1900s. We tested the hypothesis that the native vegetation has not recovered from this exotic disturbance by evaluating differences in canopy cover of shrubs, grasses, and forbs between paired sets of historically dry-farmed land and adjacent never-cultivated areas. Paired sites were located in three ecological sites in northwestern Utah. We found that vegetation recovery from cultivation is variable by growth form, species, and ecological site. Shrub recovery was different among sagebrush (Artemisia) species. Yellow rabbitbrush (Chrysothamnus viscidiflorus [Hook.] Nutt.) and black greasewood (Sarcobatus vermiculatus [Hook.] Torr.), which often increase following disturbance, maintained higher cover inside old fields. At one of the paired sets, shrub composition was altered from a mix of four species to dominance of mainly Wyoming big sagebrush (Artemisia tridentata Nutt. subsp. wyomingensis Beetle \& Young). Total forb cover was generally lower in cultivated areas and some species, such as spiny phlox (Phlox hoodii Richardson), had not recovered. The most common grass species encountered across all ecological sites, bottlebrush squirreltail (Elymus elymoides [Raf.] Swezey), had higher cover in cultivated areas. Surprisingly, exotic annual species, such as cheatgrass (Bromus tectorum L.), did not dominate these sites as they have for decades after cultivation in other areas of the Great Basin. This study demonstrates that the land-use legacy of dry farming on vegetation remains nearly a century after cultivation has ceased, and has direct implications for describing ecological site conditions.
\end{abstract}

\section{Resumen}

Es sabido que la actividad agrícola altera los procesos ecológicos y las comunidades de plantas nativas pueden requerir décadas o siglos para recuperarse del disturbio provocado por el cultivo. La "Recuperación" es mide normalmente, comparando un sitio con disturbio con otro sin disturbio como control. La recuperación de los ecosistemas de artemisa del Great Basin, en los Estados Unidos de Norteamérica permanece sin investigar aun cuando cerca de medio millón de hectáreas de tierra fueron abiertas al cultivo y después abandonadas a principios del 1900. Probamos la hipótesis de que la vegetación nativa no se ha recuperado de ese disturbio, evaluando diferencias en la cubierta del dosel de arbustos, pastos y hierbas entre parcelas pares; una históricamente cultivada en condiciones de temporal y otra parcela adyacente nunca cultivada. Las parcelas apareadas fueron ubicadas en tres sitios ecológicos en la parte noroeste de Utah. Encontramos que la recuperación de la vegetación por efecto del cultivo es variable por formas de crecimiento, especies y sitio ecológico. La recuperación de los arbustos fue diferente entre las especies de artemisas. Las especies Chrysothamnus viscidiflorus (Hook.) Nutt. y Sarcobatus vermiculatus (Hook.) Torr. que normalmente incrementan después del disturbio mantuvieron alta cobertura en las tierras de cultivo abandonadas. En uno de los grupos de parcelas, la composición de arbustos fue dominada principalmente, por cuatro especies Artemisia tridentata Nutt. subsp. wyomingensis Beetle \& Young. La cubierta de hierbas fue generalmente baja en áreas cultivadas y algunas especies como Phlox hoodii Richardson no tuvieron recuperación. La especie de pasto comúnmente encontrada en todos los sitios ecológicos fue, Elymus elymoides (Raf.) Swezey que mostro alta cobertura en areas cultivadas. Sorpresivamente, especies exóticas anuales como Bromus tectorum L no dominaron esos sitios como lo han hecho por décadas en tierras abiertas al cultivo en otras partes de la Great Basin. Este estudio demuestra que la herencia dejada por la agricultura en condiciones de temporal se mantiene después de casi un siglo que la actividad agrícola haya terminado y tiene implicaciones directas para describir la condición de sitio ecológico.

Key Words: alternate stable states, dry farming, ex-arable fields, old fields, secondary succession, site history

\section{INTRODUCTION}

This research was funded by the US Dept of Agriculture, Agricultural Research Service Area-wide Ecologically Based Invasive Plant Management project.

Correspondence: Lesley R. Morris, US Dept of Agriculture, Agricultural Research Service, Forage and Range Research Laboratory, Utah State University, 696 North 1100 East, Logan, UT 84322-6300, USA. Email: LesleyRMorris@gmail.com

Manuscript received 3 September 2010; manuscript accepted 10 May 2011.
Conversion of wildland ecosystems to agricultural crop cultivation has occurred worldwide with impacts that last for decades to centuries (Foster et al. 2003; Cramer et al. 2008). In the broadest sense, these conversions alter important ecosystem properties including vegetation structure and function, soil 
structure and chemistry, nutrient dynamics, and hydrology (Standish et al. 2006, 2007). Consequently, native species recovery after cultivated lands are abandoned may require decades (Daubenmire 1975; Rickard and Sauer 1982; Standish et al. 2007) to over half a century (Stylinski and Allen 1999; Simmons and Rickard 2002; Elmore et al. 2006). The lengthy time required for recovery may stem from the possibility that certain ecosystem properties have been altered by this "exotic" soil disturbance in a way that ecosystems may have crossed irreversible thresholds into alternate stable states (Rickard and Sauer 1982; Coffin et al. 1996; Stylinski and Allen 1999; Cramer et al. 2008). Exotic disturbances are not a part of natural disturbance regimes and can alter successional processes (Stylinski and Allen 1999). When land-use legacies have fundamentally changed the structure and function of ecosystems, ideas about conservation or restoration of these ecosystems may require significant revision from the norm (Seastedt et al. 2008; Hobbs et al. 2009).

Cultivation land-use legacies have been studied worldwide from Australia (Standish et al. 2007) to Africa (Krug and Krug 2007), and Asia (Feng et al. 2007) to Europe (Öster et al. 2009). They have also been examined in many North American ecosystems, including semiarid shortgrass steppe (Coffin et al. 1996), the Sonoran Desert (Banerjee et al. 2006), throughout the shrub-steppe and Palouse region of the Columbia River plateau (Daubenmire 1975; Rickard and Sauer 1982; Brandt and Rickard 1994; Simmons and Rickard 2002), the Northern Plains grasslands (Dormaar and Smoliak 1985; Jones et al. 2005), and eastern deciduous forests (Motzkin et al. 1996; Donohue et al. 2000). However, few studies have characterized land-use legacies on ecosystem recovery in the Great Basin region of the western interior of North America (Elmore et al. 2006).

Nearly a half million hectares of the sagebrush (Artemisia L.)-covered valleys in the arid Intermountain West were once cultivated during the dry-farming boom in the early 20th century (Stewart 1938; Pearse and Hull 1943). Dry farming is essentially agriculture without irrigation. For the most part, the dry farmers were attempting to produce wheat (Triticum aestivum L.) and other grains. The early methods of dry farming were labor intensive and created severe, exotic disturbances in these systems (Stylinski and Allen 1997). The land was cleared of sagebrush and other vegetation, plowed about 18 to $25 \mathrm{~cm}$ deep, and then harrowed with a wide frame fixed with large spikes hanging toward the ground to pulverize the soil (Scofield 1907). Although the dry-farming land boom only lasted until the early 1920s (barely over a decade), the abandoned farmlands can sometimes still be seen in aerial photos, nearly $100 \mathrm{yr}$ after these shrubland ecosystems were first cultivated (Morris and Monaco 2010).

Similar to abandoned cultivated areas around the world, these lands in the Great Basin were rapidly colonized and dominated by annual exotic weed species, especially the annual cheatgrass (Bromus tectorum L.) (Stewart and Hull 1949; Hobbs and Atkins 1991; Krug and Krug 2007). In fact, dry farming has the dubious distinction of assisting in the spread and establishment of B. tectorum into the Great Basin as a contaminant in the winter wheat and grains so widely grown in the early 1900s (Mack 1981; Knapp 1996). Once established, exotic plant dominance can persist for decades, particularly in areas dominated by B. tectorum (Hironaka 1986). Many areas in the northern Great Basin have been dominated by $B$. tectorum for at least $30 \mathrm{yr}$ (Young and Longland 1996). There is consensus that once B. tectorum gains dominance at a site, it can somehow "arrest succession" or create an alternative stable plant community, from which recovery is considered insurmountable without costly human intervention (Young and Longland 1996; Norton et al. 2004; MacKown et al. 2009).

Unfortunately, we know more about the process of deterioration on our rangelands in the United States than we do about recovery (Allen-Diaz and Bartolome 1998). In the absence of long-term data sets, vegetation "recovery" is typically measured by comparison of similarity to undisturbed adjacent sites as a control (Knapp 1992; Samuel and Hart 1994; Stylinski and Allen 1999). Using this definition, we endeavor to fill the knowledge gap regarding recovery in the northern Great Basin. We hypothesized that vegetation has not recovered on these sites because historical dry farming represents an exotic disturbance in this region. To test this hypothesis we evaluated the differences in canopy cover of shrubs, grasses, and forbs between paired sets of historically dry-farmed land (cultivated areas hereafter) and adjacent land that has never been cultivated (noncultivated areas hereafter) in each of three "ecological sites." Ecological sites describe the ecological potential and dynamics of a unit of land underlain by a distinct soil type (NRCS 2006). Specifically, we addressed the following questions: 1) Has absolute cover of shrubs, forbs, and grasses recovered on previously cultivated areas relative to identical adjacent noncultivated areas? 2) Does recovery differ between ecological sites? 3) Is recovery variable within an ecological site?

We predicted that plant cover of each plant group would differ between paired sets of cultivated and noncultivated areas. We expected both lower cover of native species and higher cover of exotic species (e.g., B. tectorum) within cultivated areas. In addition, we expected that recovery would be different between ecological sites since each site is "a distinctive kind of land, with specific physical characteristics, which differs from other kinds of land in its ability to produce a distinctive kind and amount of vegetation, and in its response to management" (NRCS 1993, p. 1). However, we believed that the paired sets within an ecological site would be similar in degree of recovery from cultivation.

\section{METHODS}

\section{Study Area}

Research was conducted in the northwestern corner of Utah at the northern edge of the Great Basin floristic region. The area is bordered by the Raft River Mountains to the north and the Grouse Creek Mountains to the west. Average annual precipitation is about $25 \mathrm{~cm}$, and annual average temperatures range from $-18^{\circ} \mathrm{C}$ to $33^{\circ} \mathrm{C}$ (WRCC 2008). Average elevation of the study areas is $1680 \mathrm{~m}$. European settlement of the Park Valley area began in the late 1860s and early 1870s. The introduction of livestock grazing to the area followed the settlers, with the heaviest use occurring prior to the 1930s. In the early 1910s, a land boom associated with dryland wheat 
farming hit the region, but dry farms were abandoned in just over a decade (Morris and Monaco 2010).

\section{Paired Sets}

We used aerial photographs from the 1950s, 1970s, 1980s, and 2000s, verified against original homestead records and tract books to locate cultivated areas that were dry-farmed in the early 1910s and then abandoned. For this study, we selected six paired sets that offered cultivated areas adjacent to noncultivated areas. Three paired sets were on private property, and three were on public land managed by the US Department of the Interior. Each paired set was located on the same ecological site with the same slope and soil type. Paired sets were always within $500 \mathrm{~m}$ of each other to keep them within the same property ownership. Therefore, grazing and management history was the same between paired sets and was similar across the ecological sites. We also used cultivated areas that were similar in size and shape, because these characteristics have been shown to influence recovery in other ecosystems (Samuel and Hart 1994).

\section{Ecological Sites}

The six paired sets, named after the patentee on the original homestead or from the tract book, were located in three different ecological sites: Semidesert Loam (Swenson; $n=1$ ), Semidesert Alkali Loam (Atherley, Unknown, and Druehl; $n=3$ ), and Semidesert Shallow Hardpan (Alder and Scott; $n=2$ ) (NRCS 1993). Ecological site descriptions (ESDs) are the smallest unit of a hierarchical nested land classification system used by resource managers in the United States (NRCS 2006). They describe ecological potential and ecosystem dynamics of land areas underlain by distinct soil types. These ESDs are used to stratify the landscape and organize ecological information for purposes of land monitoring, assessment, and management. In addition, ESDs are organized within Major Land Resource Areas (MLRA). The three ESDs used in our studies all occur within the D-28A MLRA of the Great Salt Lake Area.

The Semidesert Loam site was located on the Lembos soil series, classified as a coarse-loamy, mixed, superactive, mesic Xeric Argidurid (NRCS 2010). According to the ESD, the potential plant community (reference state without pervasive disturbances) at this site would be dominated by Wyoming big sagebrush (Artemisia tridentata Nutt. subsp. wyomingensis Beetle \& Young) with bluebunch wheatgrass (Pseudoroegneria spicata [Pursh] A. Löve) as the most common understory perennial grass (NRCS 1993). The Semidesert Alkali Loam sites occur within the ecotone between the black greasewood (Sarcobatus vermiculatus [Hook.] Torr.)-dominated Alkali Flat and the A. tridentata subsp. wyomingensis-dominated Semidesert Loam ecological sites. Our sampling was conducted on the Kunzler soil series, classified as a coarse-loamy, mixed, superactive, mesic Durinodic Heric Haplocalcid (NRCS 2010). Potential vegetation at this site would be dominated by $A$. tridentata subsp. wyomingensis and S. vermiculatus (NRCS 1993). The Semidesert Shallow Hardpan sites were sampled on the Acana soil series, classified as loamy, mixed, superactive, mesic, shallow Haploxeralfic Argidurids (NRCS 2010). Potential vegetation at this ecological site is characterized by black sagebrush (Artemisia nova A. Nelson) and the perennial grasses
Indian ricegrass (Achnatherum bymenoides [Roem. \& Schult.] Barkworth) and needle and thread grass (Hesperostipa comata [Trin. \& Rupr.] Barkworth) in the understory (NRCS 1993).

\section{Vegetation Cover Measurements}

To ensure sampling of the paired sets was carried out in similar areas with the same mapped soil series, we used global positioning system coordinates to navigate preselected linear routes $(200-300 \mathrm{~m}$ ) across each condition (cultivated/noncultivated). We began sampling at least $50 \mathrm{~m}$ within the boundary of a cultivated area or away from roads to avoid edge effects. Estimates of canopy cover were made in cultivated and noncultivated areas within $0.25-\mathrm{m}^{2}$ metal frame quadrats at 36 random positions along the three linear routes. Ocular estimates of understory canopy cover were recorded by assigning Daubenmire cover classes (1-5\%, 5-25\%, 25-50\%, $50-75 \%, 75-95 \%, 95-100 \%)$ for each species encountered (Daubenmire 1959). The quadrat frames were partitioned into four decreasing nested areas $\left(0.25 \mathrm{~m}^{2}, 0.125 \mathrm{~m}^{2}, 0.0625 \mathrm{~m}^{2}\right.$, and $0.0156 \mathrm{~m}^{2}$ ) to accommodate cover estimation of species with variable abundance and distribution. This nested frame was also used to determine frequency of species by recording the smallest nested area occupied by a species. Six locations in both cultivated and noncultivated areas were also randomly selected to record shrub cover. Shrub cover in these random locations was measured along a $20-\mathrm{m}$ transect using the line-intercept method (Bonham 1989). All data were collected in May through July of 2009. Taxonomy of plant species follows the USDA PLANTS database (USDA NRCS 2010).

\section{Statistical Analysis}

Numerous attempts were made to improve data normality using transformations, yet none adequately reached the assumptions for parametric analysis. Therefore, we used Wilcoxon rank sums for matched pairs to compare response variables of the six paired sets by ecological site. Midpoints of the Daubenmire cover classes $(2.5 \%, 15 \%, 37.5 \%, 62.5 \%$, $85 \%$, and $97.5 \%$ ) were used for analyzing the understory canopy cover. Means are presented graphically for interpretation with one standard error, although all analyses were Wilcoxon rank sums for matched pairs.

In addition, because parametric statistical methods were unavailable to further elucidate relationships between paired sets and ecological sites, we performed post hoc analysis of species composition in ordination space with nonmetric multidimensional scaling (NMDS). The NMDS analysis was conducted on species frequency data in the statistical software R using the "vegan package," which is designed for ecological data and set for Bray-Curtis as a metric of distance (Holland 2008).

\section{RESULTS}

\section{Shrub Canopy Cover}

In the Semidesert Loam site, $A$. tridentata cover was significantly lower in the cultivated area $(n=6 ; Z=2.65, P=0.01)$, whereas yellow rabbitbrush (Chrysothamnus viscidiflorus [Hook.] Nutt.) 

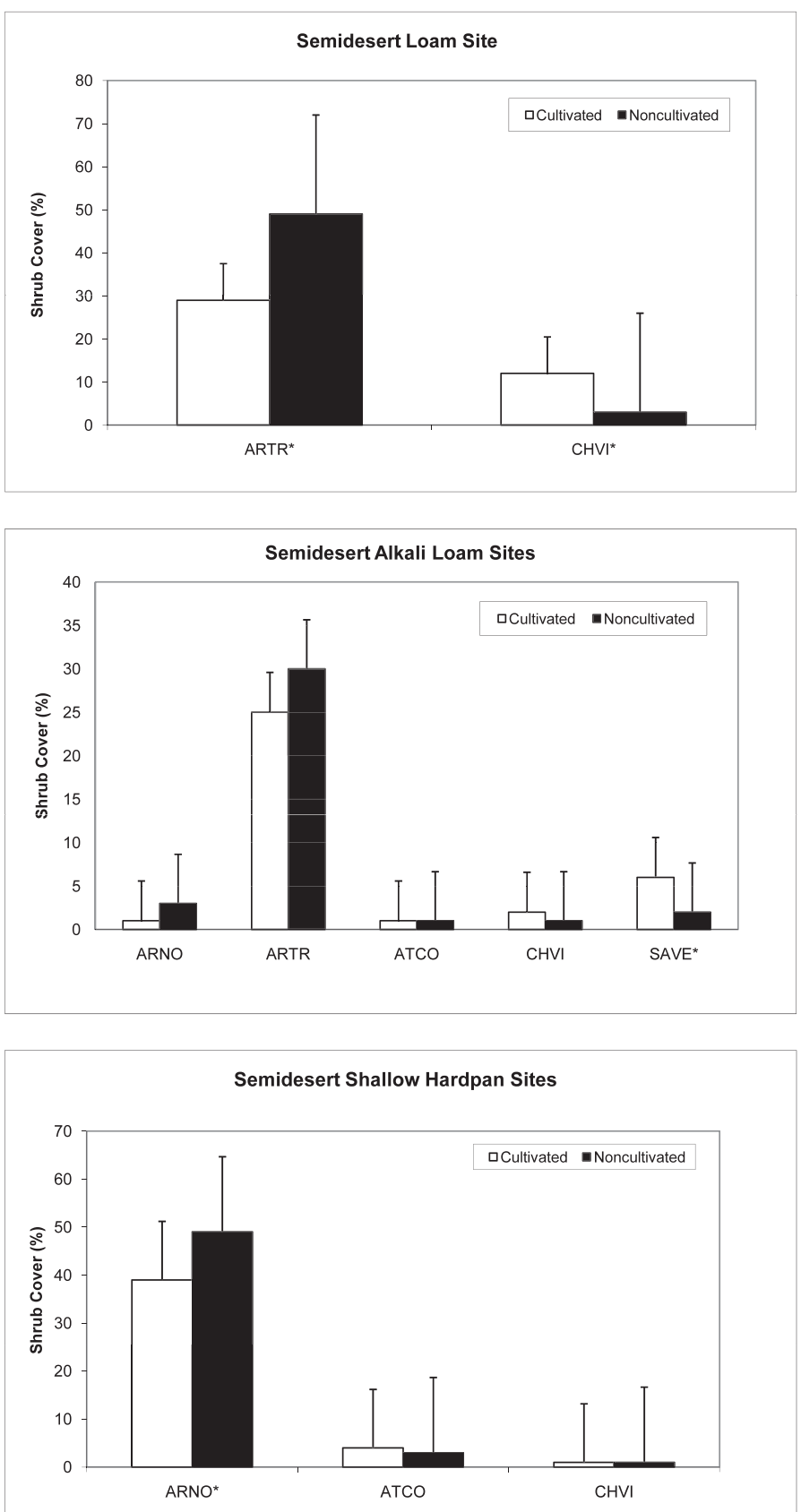

Figure 1. Shrub cover from cultivated and noncultivated areas at each of the three ecological sites. ARNO indicates Artemisia nova; ATCO, Atriplex confertifolia; ARTR, Artemisia tridentata; CHVI, Chrysothamnus viscidiflorus; and SAVE, Sarcobatus vermiculatus. Graphs show mean ( $\pm 1 \mathrm{SE}$ ), and analysis is Wilcoxon rank sums; * indicates $P<0.05$.

cover was significantly higher in the cultivated area $(Z=-1.93$, $P=0.04$ ) (Fig. 1). In the Semidesert Alkali Loam sites, only cover of $S$. vermiculatus was significantly higher in cultivated areas $(n=18 ; Z=-2.38, P=0.02)$. In the Semidesert Shallow Hardpan sites, only the cover of $A$. nova was significantly lower in the cultivated areas $(n=12 ; Z=2.95, P=0.003)$.

One of the Semidesert Alkali Loam paired sets (Druehl) stood out from the rest in its differences in composition of shrub cover. The shift in shrub species cover between cultivated and noncultivated sites could be seen on the ground and in the cover data collected for this paired set (Fig. 2). In the

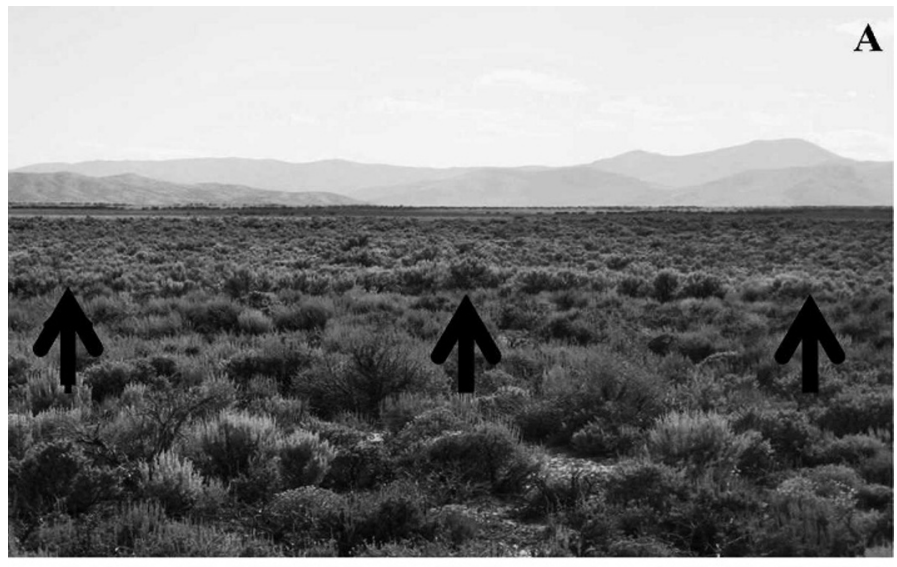

B
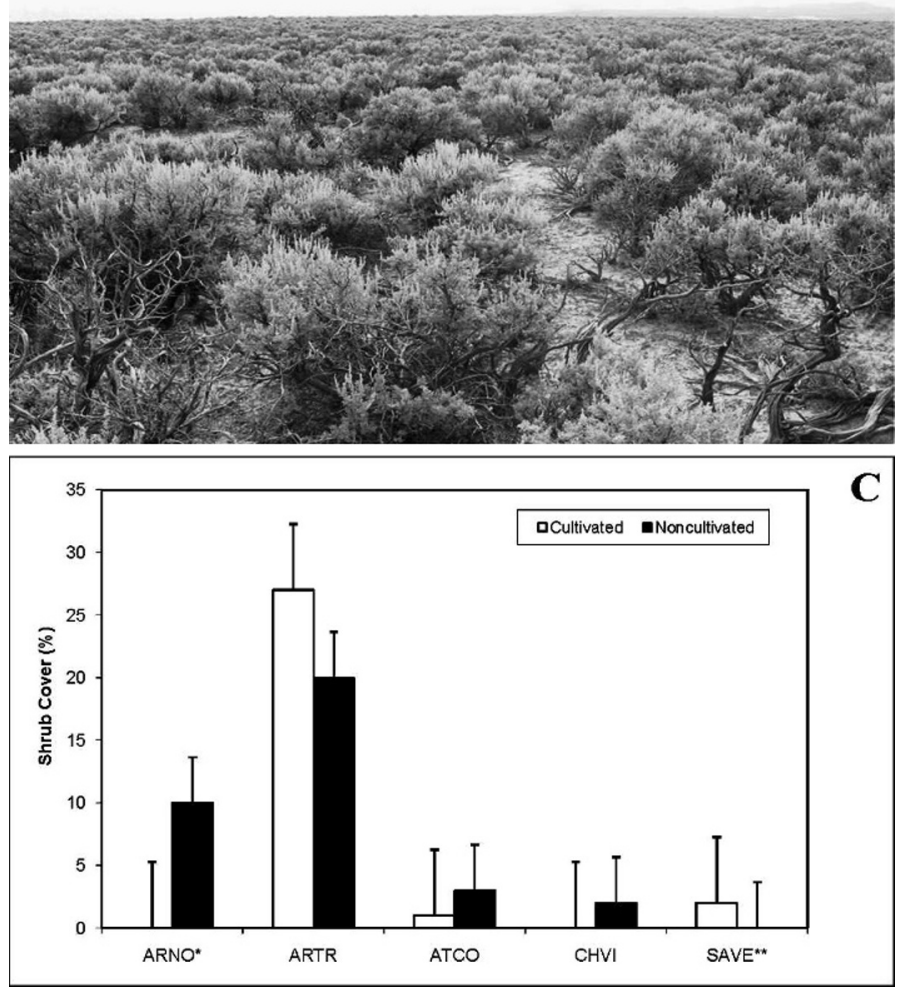

Figure 2. A, Druehl paired set in Semidesert Alkali Loam site showing edge of the cultivated area in middle of photo (see arrows) and noncultivated area in foreground. B, Cultivated area on which Artemisia tridentata contributed almost $100 \%$ of shrub cover. C, Differences in shrub cover between cultivated and noncultivated areas, mean ( $\pm 1 \mathrm{SE})$ shrub cover. Analysis is Wilcoxon rank sums; * indicates $P<0.05$; **, $P<0.01$.

noncultivated area, shrub cover was dominated by $A$. tridentata, with a mix of other shrubs. Inside the cultivated area, cover was dominated almost entirely by $A$. tridentata.

\section{Forb Canopy Cover}

Total forb cover (native and exotic) was lower within the cultivated areas in both the Semidesert Loam site $(n=36$; $Z=4.81, P<0.0001)$ and the Semidesert Alkali Loam site $(n=108 ; Z=3.32, P=0.0009)$. In contrast, total forb cover in the Semidesert Shallow Hardpan site was not different between 

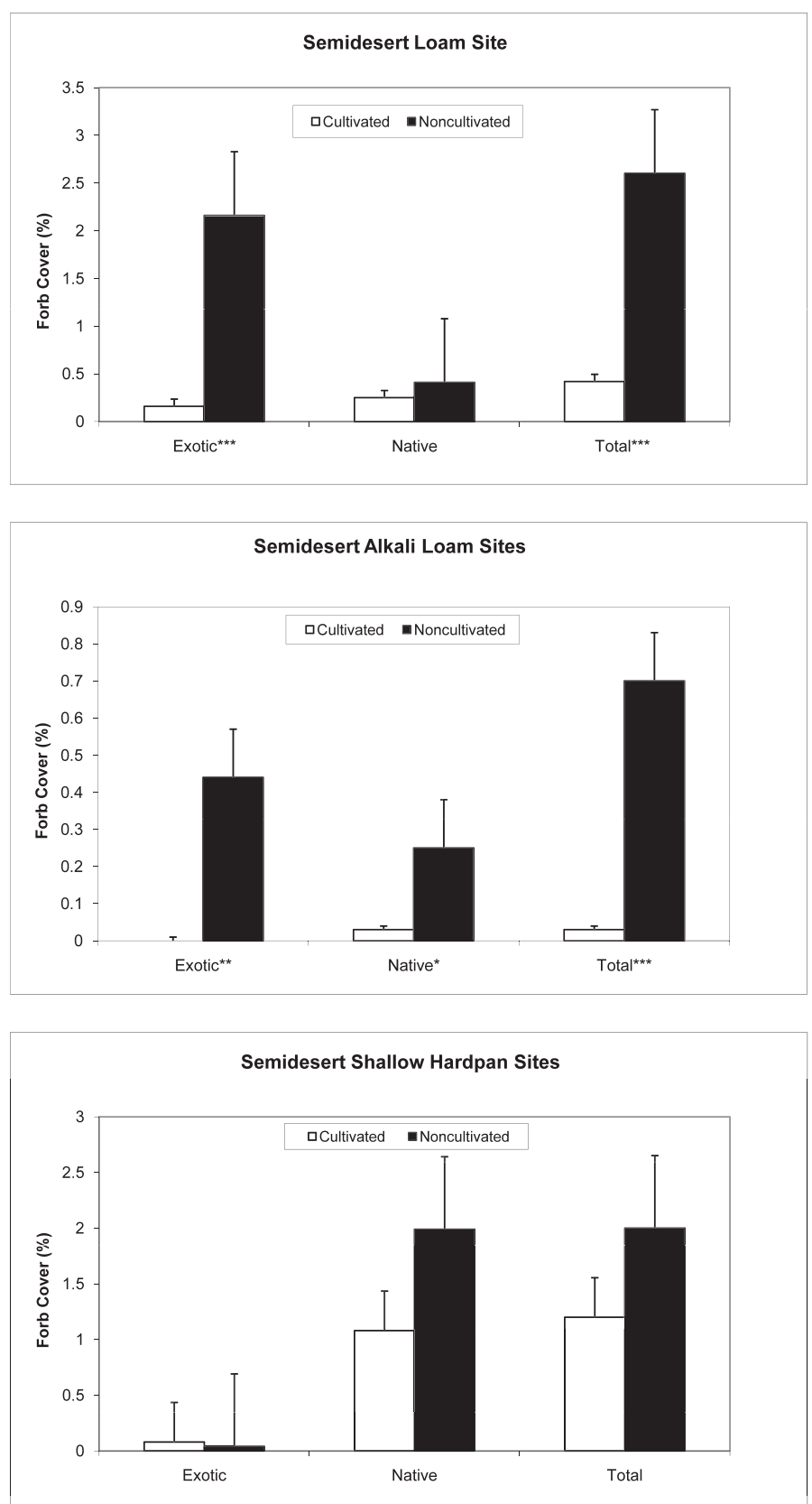

Figure 3. Exotic, native and total forb cover from cultivated and noncultivated areas at each of three ecological sites. Graphs show the mean ( $\pm 1 \mathrm{SE}$ ). All analyses are Wilcoxon rank sums; * indicates $P<0.05 ;{ }^{*}, P<0.01 ;{ }^{* *}, P<0.0001$.

cultivated and noncultivated areas (Fig. 3). Exotic forb cover was significantly lower in the cultivated areas at both the Semidesert Loam site $(Z=5.54, P<0.0001)$ and at the Semidesert Alkali Loam sites $(Z=-3.04, P=0.002)$. Native forb cover was significantly lower in cultivated areas at the Semidesert Alkali Loam sites $(Z=5.54, P=0.02)$. There were no significant differences in exotic or native forb cover between cultivated and noncultivated areas at the Semidesert Shallow Hardpan sites.

There were few significant differences in cover of individual forb species between cultivated and noncultivated areas. The exception was the native species spiny phlox (Phlox hoodii Richardson), which had lower cover in the cultivated areas
Table 1. Forbs by paired set, cultivated/noncultivated, within each ecological site. ${ }^{1}$

\begin{tabular}{c}
\hline Cultivated \\
\hline$------------\%$ Cover mean (SE) ------------
\end{tabular}

Semidesert Loam

"Swenson" paired set

Ceratocephala testiculata

$0.08(0.08)$

Chaenactis douglasii

$0.08(0.08)$

Descurainia sophia

$0.08(0.08)$

Phlox longifolia

$0.17(0.11)$

Total no. of species [exotic]

4 [2]

$0.33(0.15)$

Semidesert Alkalai Loam

"Atherley" paired set

Ceratocephala testiculata

Chaenactis douglasii

Descurainia sophia

Total No. of species [exotic]

"Unknown" paired set

Descurainia sophia

Phlox hoodii

Total no. of species [exotic]

"Druehl" paired set

Descurainia sophia

Total no. of species [exotic]

$1.75(1.75)^{2}$
$1[1]$

Semidesert Shallow Hardpan

"Alder" paired set

Descurainia sophia

Phlox longifolia

Phlox hoodii

Total no. of species [exotic]

$\begin{array}{cc}0 & 0.08(0.08) \\ 0.08(0.08) & 0 \\ 1[0] & 2[1]\end{array}$

$0.84(0.45)^{\star *}$

$0.42(0.17)^{*}$

$0.42(0.17)^{\star}$

5 [2]

Scott" paired set

Phlox longifolia

Phlox hoodii

Total no. of species [exotic]

$0.1(0.08)$

$0.1(0.08)$

$1.5(0.25)^{*}$

$0.8(0.22)$

$0.2(0.12)$

$6[1]$

$2.1(0.82)^{\star}$

5 [1]

${ }^{1}$ Wilcoxon ranked sums for paired sites. * indicates $P<0.05$; ${ }^{* *}, P<0.01$; ${ }^{* * *}, P<0.001$.

${ }^{2} O$ nly one large plant was encountered. It was considered an outlier and not used in analysis.

$(0.08 \pm 0.06)$ than in the noncultivated areas $(1.15 \pm 0.43$; $n=72 ; Z=2.63, P<0.01)$ at the Semidesert Shallow Hardpan sites. Other species' cover was significantly different across paired sets but not for the ecological site (Table 1). These included the native forbs longleaf phlox (Phlox longifolia Nutt.) and Douglas' dustymaiden (Chaenactis douglasii [Hook.] Hook. \& Arn.), and the exotic forbs curveseed butterwort (Ceratocephala testiculata [Crantz] Roth) and flixweed (Descurainia sophia [L.] Webb ex Prantl). Mean cover of $P$. longifolia was significantly higher in the cultivated area at the Alder paired set $(n=36 ; Z=-1.91, P=0.05)$. In addition, there was significantly more cover of $C$. testiculata in the noncultivated areas at both the Swenson paired set $n=36$; $Z=5.64, P<0.0001)$ and the Atherley paired set $(n=36$; $\mathrm{Z}=2.52, P=0.01)$. Finally, there was significantly higher cover of $D$. sophia $(n=36 ; Z=2.29, P=0.02)$ and $C$. douglasii $(n=36 ; Z=2.29, P=0.02)$ in the noncultivated area at the Atherley paired set. 

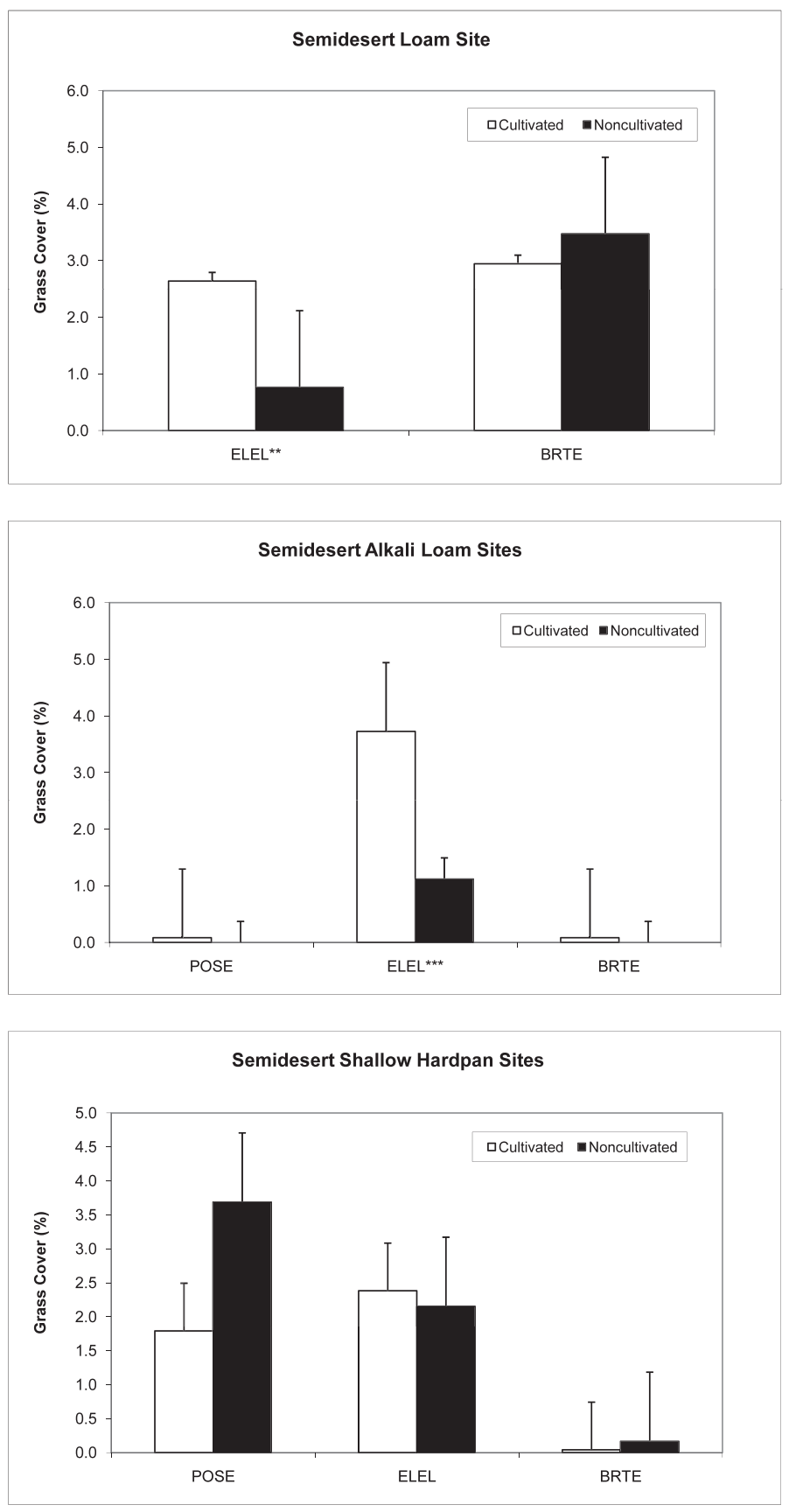

Figure 4. Grass cover from cultivated and noncultivated areas at each of three ecological sites. ELEL indicates Elymus elymoides; BRTE, Bromus tectorum; POSE, Poa secunda. Graphs represent mean ( $\pm 1 \mathrm{SE}$ ), and analysis is Wilcoxon rank sums; ${ }^{* *}$ indicates $P<0.01$; ${ }^{* *}, P<0.0001$.

\section{Grass Canopy Cover}

The native grass bottlebrush squirreltail (Elymus elymoides [Raf.] Swezey) had significantly higher cover in cultivated areas in the Semidesert Loam site $(n=36 ; Z=-2.62, P<0.01)$ (Fig. 4$)$ and in the Semidesert Alkali Loam sites $(n=108 ; Z=-4.24, P<0.0001)$. There were no differences in grass cover between cultivated and noncultivated areas in the Semidesert Shallow Hardpan sites.

\section{Differences Between and Within Ecological Sites}

There was a two-axis NMDS solution for species composition (Fig. 5). Final stress was 10.4, within the 10-20 range typically

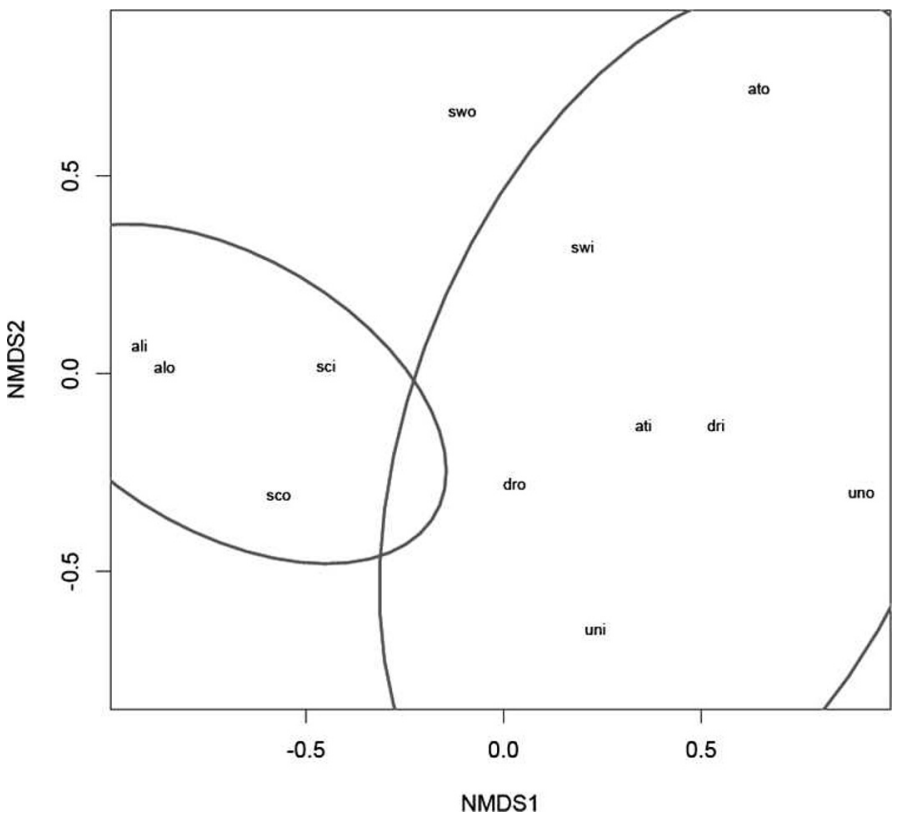

Figure 5. Species composition among ecological sites and between paired sets within ecological sites represented in nonmetric multidimensional scaling space. Ellipses are used to delineate between two ecological sites. The smaller ellipse (left) represents the Semidesert Shallow Hardpan site and the relatively larger ellipse (right) represents the Semidesert Alkali Loam site. There was only one paired set within the Semidesert Loam site, so no ellipse can be presented. The paired sites are represented by the patentee's name (sw indicates Swenson; al, Alder; sc, Scott; at, Atherley; un, unknown; and dr, Druehl) and cultivation condition (i indicates cultivated area; and 0, noncultivated area).

found in plant community data sets (McCune and Grace 2002). Dissimilarity is indicated by ordination distance in NMDS. In other words, paired sets that are farther apart are more dissimilar and less recovered. For interpretation, we included ellipses representing one standard deviation around the centroid for each ecological site. There is no ellipse for the Semidesert Loam Site because there was only one paired set. The paired sets and overall grouping in the Semidesert Shallow Hardpan site are less scattered than the Semidesert Alkali Loam site.

\section{DISCUSSION}

Our results support the hypothesis that the native vegetation has not recovered from the exotic disturbance of dry farming on these shrubland ecosystems in the Great Basin. Even $90 \mathrm{yr}$ after cultivation ceased, quantitative differences in plant cover exist between cultivated areas and adjacent noncultivated land. Our results indicate that recovery (defined as similarity between cultivated and noncultivated areas) is variable across ecological sites, suggesting that the legacy effects of this historical land use can differ across a landscape. This is the first report of different ecological sites interacting with exotic disturbances, such as dry farming, to influence vegetation recovery. Unexpectedly, recovery was also variable between growth form, genus, species, and paired sets within an ecological site. Understanding these differences in recovery has important implications for how we classify and interpret 
the condition of shrublands, as well as how we attempt to rehabilitate them.

\section{Shrub Canopy Recovery}

Our study shows that sagebrush recovery from dry farming in the Great Basin may take more than $90 \mathrm{yr}$ in some ecological sites, which is longer than other exotic and native disturbances (Stylinski and Allen 1997; Baker 2006). Other research about sagebrush recovery from exotic disturbances comes from treatments to reduce shrub cover (e.g., plowing, disking, burning, and herbicide control) and the seeding of introduced grasses to increase forage production. For example, Watts and Wambolt (1996) studied four different disturbances in southwestern Montana and reported that each disturbance produced different temporal patterns and pathways of recovery for $A$. tridentata subsp. wyomingensis. In particular, they found that shrubs recovered more slowly from burning than from a onetime plowing and seeding with grasses. On the other hand, Baker (2006) concluded in his review that $A$. tridentata recovery from fire will require "35 or more years" (p. 183). Furthermore, in an area near our study sites, Colket (2003) found that 53-92 yr were required for $A$. tridentata density to recover from fire.

Our results also show that a higher cover of disturbancemediated shrub species, such as C. viscidiflorus and $S$. vermiculatus, can persist in cultivated areas. At the Semidesert Loam site, C. viscidiflorus had higher cover inside the old field. This result is consistent with results from similar species in our region. Elmore et al. (2006) found significantly higher cover of rubber rabbitbrush (Ericameria nauseosa [Pall. ex Pursh] G.L. Nesom \& Baird) on abandoned agricultural land than noncultivated sites at the southern end of the Great Basin. However, our results conflict with Simmons and Rickard (2002), who found higher frequency and density of C. viscidiflorus on noncultivated rather than cultivated areas in the Columbia Basin. Similarly, S. vermiculatus had higher cover inside the cultivated areas in the Semidesert Alkali Loam sites. This is an important finding because the ESDs for both the Semidesert Loam and the Semidesert Alkali Loam sites state that C. viscidiflorus and S. vermiculatus will increase following deterioration from overgrazing or after a fire (NRCS 1993). Not understanding the land-use history at these sites could lead to misinterpretation of their condition, because the dynamics described in the ESDs do not include any consideration of land-use legacies other than grazing.

Finally, we found that the land-use legacy of dry farming can alter shrub composition. The change in species composition at the Druehl paired set in the Semidesert Alkali Loam ecological site is of particular interest. An historical plow line has been observed before (Samuel and Hart 1994), but this kind of transition in the shrub community has not been previously documented in the Great Basin. Although all the paired sets were visible in aerial photographs, this is the only instance among the six sets where an abrupt vegetation change could be discerned on the ground. One possible explanation for the shift in shrub composition is that the cultivated area is in an ecotonal ecological site. Ecotonal sites can be predisposed to plant community change under disturbances (Gosz 1993). Soil mixing during cultivation could have altered this site to favor some species over others. However, the other two pairs within this ecotone did not exhibit this abrupt contrast (data not shown). Therefore, it is also plausible that shift in shrub composition at this paired set is influenced by differences in historical cultivation practices and equipment (Coffin et al. 1996; Buisson and Dutoit 2004).

\section{Forb Canopy Recovery}

Recovery of overall forb cover from historical cultivation was only observed in the Semidesert Shallow Hardpan ecological site. In contrast, the other two ecological sites maintained significantly lower forb cover inside cultivated areas. Our results are consistent with lower frequency and cover of forbs found in cultivated areas abandoned for 30-57 $\mathrm{yr}$ in the Columbia Basin sagebrush steppe (Rickard and Sauer 1982; Simmons and Rickard 2002) and in cultivated areas abandoned for $60 \mathrm{yr}$ in the Northern Plains of Canada (Dormaar and Smoliak 1985). We observed that most of the exotic forb cover (e.g., C. testiculata and D. sophia) occurred on the noncultivated areas. This finding is inconsistent with other studies where exotic forb cover is higher in cultivated areas up to $70 \mathrm{yr}$ after abandonment (Stylinski and Allen 1999).

The response of the native $P$. hoodii in our study follows what is known about how cultivation and intense soil disturbances reduce its abundance (Reeves et al. 1979). It can recover from fire vegetatively but must establish from seed if the entire plant is removed, as would be the case in dry farming (Gucker 2006). The absence of $P$. hoodii may be a useful indicator of historical cultivation disturbances where historical records are incomplete.

As with shrubs, recovery of forb species was different between the ecological sites as well as within them. Higher mean cover of $P$. longifolia in the cultivated area in the Alder paired set was unexpected because it does not agree with the results of studies in the Columbia Basin sagebrush steppe (Daubenmire 1975; Rickard and Sauer 1982; Simmons and Rickard 2002). Given that forbs are particularly important for restoration and the management of wildlife species such as the sage grouse (Connelly et al. 2000; Wrobleski and Kauffman 2003; Walker and Shaw 2005), forb recovery in historically cultivated shrublands deserves further study.

\section{Grass Canopy Recovery}

Grass cover appears to have recovered in the Semidesert Shallow Hardpan sites because there were no differences between cultivated and noncultivated areas. However, there was more cover of E. elymoides in cultivated areas in both the Semidesert Loam and the Semidesert Alkali Loam sites. Daubenmire (1975) also observed high cover of E. elymoides in fields abandoned for 39-52 years in the Columbia Basin sagebrush steppe, even though it was not present in surrounding noncultivated sites. Hironaka and Tisdale (1963) reported what they believed was the first occurrence of an annualdominated system of $B$. tectorum returning to perennial grass dominance when a native E. elymoides became more frequent than the exotic annual grass $10 \mathrm{yr}$ after the field was abandoned. Elymus elymoides has been referred to as a "transitional dominant" wherein it can occupy an area early after disturbance, suppress B. tectorum on the site, and facilitate reestablishment of Artemisia spp. (Booth et al. 
2003; Young et al. 2003). Our one-time sampling cannot address how E. elymoides gained dominance within cultivated areas. However, the unassisted recovery and dominance of E. elymoides suggests that this species may be a good choice for restoration of exotically disturbed sites (Jones 1998; Booth et al. 2003; Leger 2008).

The minimal cover of $B$. tectorum across cultivated areas was surprising because other areas in Park Valley had a high cover of $B$. tectorum the same year we sampled (data not shown). We had predicted that cultivated areas would be dominated by $B$. tectorum because in other studies of abandoned cultivation in sagebrush systems, this annual grass and other exotic species persisted and even dominated sites for $30 \mathrm{yr}$ to over half a century after cultivation ceased (Daubenmire 1975; Rickard and Sauer 1982; Elmore et al. 2006). Furthermore, in Australia, where there are similar patterns in exotic annual grasses dominating abandoned dry-farm wheat fields, exotic annuals have remained dominant for up to $45 \mathrm{yr}$ (Standish et al. 2007). It is commonly believed that $B$. tectorum may "never relinquish control of secondary succession" (Young and Longland 1996, p. 388). Long-term dominance by B. tectorum is believed to represent an alternate stable state in which significant active human inputs must be expended in order to transition sites to a more desirable state (Stewart and Hull 1949; Allen-Diaz and Bartolome 1998; Norton et al. 2004). Although we do not have any cover data for B. tectorum on our paired sets prior to this study, longtime local residents report that the cultivated areas we studied were covered with exotic annual weed species in the past. Aerial photos from 1957 indicate these areas were open and/or covered with forbs and grasses. Observations made nearby our study area during the 1920s indicate that abandoned dry farms were typically weedy, and contained abundant B. tectorum (Piemeisel 1938; Daubenmire 1975; Morris 2006). If these annuals dominated at one time, they do not any longer.

It is important to point out that the potential vegetation for the Semidesert Loam site is expected to have an understory dominated by the native bunchgrass of $P$. spicata (NRCS 1993), yet it was not encountered in cultivated or noncultivated areas. In addition, the ESD for the Semidesert Alkali Loam site suggests that the native grass component could be dominated on a dry mass basis by E. elymoides, Nevada bluegrass (Poa nevadensis), and A. hymenoides. However, irrespective of historical cultivation, these other two native grasses were not encountered within sampling frames at this ecological site. Finally, the potential vegetation for Semidesert Shallow Hardpan site suggests the occurrence of A. hymenoides and $H$. comata, but these species were not encountered in either site. Livestock grazing, particularly prior to 1930 , is likely to have reduced the abundance of these grasses (and forbs) across all sites prior to cultivation. Their occurrence may now be further limited by low representation in the seed bank and by few sources for seed dispersal from the surrounding areas.

\section{Recovery Between and Within Ecological Sites}

The NMDS analysis revealed many important aspects of variation between and within ecological sites. First, minimal overlap of ellipses between the Semidesert Shallow Hardpan and Semidesert Alkali Loam ecological sites support the expectation that ecological sites fundamentally differ in their potential to produce and sustain distinctive kinds and amounts of vegetation. Second, although larger ellipses are expected for the ecotonal Semidesert Alkali Loam site relative to the Semidesert Shallow Hardpan site, the closer grouping of paired sets in the latter suggests that more recovery has taken place in this ecological site. This is congruent with our other findings of no differences in grass cover, total forb cover, or exotic species cover in cultivated and noncultivated areas in the Semidesert Shallow Hardpan site. With the exception of $A$. nova and $P$. hoodii cover, this ecological site had mostly recovered. Furthermore, less grouping of the paired sets in NMDS space for the Semidesert Alkali Loam site is supported by our observations that shrub and forb cover have not recovered in this site. Third, variation in grouping of paired sets for the Semidesert Shallow Hardpan and Semidesert Alkali Loam ecological sites suggests that recovery also differs within ecological sites. These differences in recovery between and within ecological sites could also be due to other factors. Vegetation is heterogeneous across landscapes, even within an ecological site. Although we carefully selected and randomly sampled our paired sets, their location is confounded with cultivation. It could also be that ecological site designation is less important in determining recovery than historical farming practices at each paired set. In fact, current vegetation on formerly cultivated land can have more connection to historical land use and management than prevailing climate or soil resource status (Motzkin et al. 1999; Buisson and Dutoit 2004). Differences in recovery between the two ecological sites could also be due to a number of variables that we did measure, such as the condition of surrounding noncultivated land. Quantifying differences in soil attributes and plant resource acquisition between ecological sites and cultivated and noncultivated areas will likely provide a more comprehensive assessment for differences in recovery.

\section{IMPLICATIONS}

Our results show that land-use legacies of past cultivation have important implications for land management, classification and interpretation of shrubland condition, and future rehabilitation. Although cultivation history is not currently included in ESDs, our results show it can influence "the kind and amount of vegetation" on sites and, therefore, this land-use history is necessary to fully predict and anticipate the dynamics and successional pathways within an ecological site. For example, the change in shrub composition at the Druehl paired set in the Semidesert Alkali Loam site suggests this site may not return to the potential described in the ESD. Furthermore, the current vegetation in many of these old fields would typically be attributed to grazing management. These misinterpretations have the potential to be widespread because there are likely half a million hectares with dry farming legacies in the western United States. It was estimated that nearly 9307770 ha of rangeland were cultivated by the late 1930s (Stewart 1938). Furthermore, with abandonment of agricultural land increasing worldwide, understanding historical land use is becoming increasingly important for land managers around the globe (Cramer et al. 2008). 
Many restoration initiatives end in failure, and there are several recent efforts to use successional management as a guiding framework for revegetation (Sheley et al. 2006). Successional management models have identified three underlying "causes of succession"- - site availability, species availability, and species performance (Pickett et al. 1987; Whisenant 1999; Sheley et al. 2006). Successional management seeks to modify and repair these processes such that plant communities are set back on a trajectory toward desired plant communities (Sheley et al. 2006, 2009). Our research shows these processes may require over a century to recover on their own. It also raises questions about whether historically dry-farmed sites can be altered to the point that the potential natural vegetation state is no longer attainable. It is possible that the exotic disturbance of cultivation can transition sagebrush ecosystems past a theoretical threshold into an alternative state (Cramer et al. 2008). Therefore, more research is needed to examine how historical land uses such as dry farming could alter the expected potential for plant communities and how these legacies interact with other disturbances.

\section{ACKNOWLEDGMENTS}

Special thanks to Justin Williams, Rob Watson, Merilynn Hirsch, and Beth Fowers for their hard work in the field. We also want to thank the private property owners in Utah and the US Department of the Interior, Bureau of Land Management, Salt Lake City Field Office, Utah, for access to the old fields used in this study. Brock Benson, from the Utah Natural Resources Conservation Service, was instrumental in introducing us to the people and the land-use history in our study area. Josh Leffler assisted with the NMDS analysis and Figure 5 .

\section{LITERATURE CITED}

Allen-Diaz, B., and J. W. Bartolome. 1998. Sagebrush-grass vegetation dynamics: comparing classical and state-transition models. Ecological Applications 8:795-804.

BAKER, W. L. 2006. Fire and restoration of sagebrush ecosystems. Wildlife Society Bulletin 34:177-185.

Baner.ee, M. J., V. J. Gerhart, and E. P. Glenn. 2006. Native plant regeneration on abandoned desert farmland: effects of irrigation, soil preparation, and amendments on seedling establishment. Restoration Ecology 14:339-348.

Bonham, C. D. 1989. Measurements for terrestrial vegetation. New York, NY, USA: John Wiley and Sons. 338 p.

Booth, M. S., M. M. Caldwell, and J. M. Stark. 2003. Overlapping resource use in three Great Basin species: implications for community invasibility and vegetation dynamics. Journal of Ecology 91:36-48.

Brandt, C. A., and W. H. Rickard. 1994. Alien taxa in the North American shrubsteppe four decades after cessation of livestock grazing and cultivation agriculture. Biological Conservation 68:95-105.

Buisson, E., and T. Dutolt. 2004. Colonisation by native species of abandoned farmland adjacent to a remnant patch of Mediterranean steppe. Plant Ecology 174:371-384.

Coffin, D. P., W. K. Lauenroth, and I. C. BuRke. 1996. Recovery of vegetation in semiarid grassland 53 years after disturbance. Ecological Applications 6:538-555.

CoLkET, E. C. 2003. Long-term vegetation dynamics and post-fire establishment patterns of sagebrush steppe [thesis]. Moscow, ID, USA: University of Idaho. $154 \mathrm{p}$.

Connelly, J. W., M. A. Schroeder, A. R. Sands, and C. E. Braun. 2000. Guidelines to manage sage grouse populations and their habitats. Wildlife Society Bulletin 28:967-985

Cramer, V. A., R. J. Hobbs, and R. J. Standish. 2008. What's new about old fields? Land abandonment and ecosystem assembly. Trends in Ecology \& Evolution 23:104-112.
Daubenmire, R. 1959. A canopy-coverage method of vegetation analysis. Northwest Science 33:43-64.

DaubenmiRe, R. 1975. Plant succession on abandoned fields, and fire influences, in a steppe area in southeastern Washington. Northwest Science 49:36-48.

Donohue, K., D. R. Foster, and G. Motzkin. 2000. Effects of the past and the present on species distribution: land-use history and demography of wintergreen. Journal of Ecology 88:303-316.

DormaAR, J. F., AND S. Smoliak. 1985. Recovery of vegetative cover and soil organic matter during revegetation of abandoned farmland in a semiarid climate. Journal of Range Management 38:487-491.

Elmore, A. J., J. F. Mustard, S. P. Hamburg, and S. J. Manning. 2006. Agricultural legacies in the Great Basin alter vegetation cover, composition, and response to precipitation. Ecosystems 9:1231-1241.

Feng, D., S. Hong-Bo, S. Lun, L. Zong-Suo, and S. Ming-An. 2007. Secondary succession and its effects on soil moisture and nutrition in abandoned oldfields of hilly region of Loess Plateau, China. Colloids and Surfaces B: Biointerfaces 58:278-285.

Foster, D., F. Swanson, J. Aber, I. Burke, N. Brokaw, D. Tilman, and A. Knapp. 2003. The importance of land-use legacies to ecology and conservation. BioScience 53:77-88.

Gosz, J. R. 1993. Ecotone hierarchies. Ecological Applications 3:369-376.

GuCkeR, C. L. 2006. Phlox hoodii. Fire effects information system, US Department of Agriculture, Forest Service, Rocky Mountain Research Station, Fire Sciences Laboratory. Available at: http://www.fs.fed.us/database/feis/. Accessed 25 July 2010

Hironaka, M. 1986. Piemeisel exclosures. Rangelands 8:221-223.

Hironaka, M., AND E. W. Tisdale. 1963. Secondary succession in annual vegetation in southern Idaho. Ecology 44:810-812.

HobBs, R. J., AND L. Atkins. 1991. Interactions between annuals and woody perennials in a Western Australian nature reserve. Journal of Vegetation Science 2:643-654.

HobBs, R. J., E. Higgs, and J. A. HarRis. 2009. Novel ecosystems: implications for conservation and restoration. Trends in Ecology \& Evolution 24:599-605.

HolLand, S. M. 2008. Non-metric multidimensional scaling (MDS). Available at: http:// www.uga.edu/strata/software/pdf/mdsTutorial.pdf. Accessed 25 July 2010.

Jones, P. F., R. Tenniket, L. Fent, J. Nicholson, and B. Adams. 2005. Silver sagebrush community associations in southeastern Alberta, Canada. Rangeland Ecology \& Management 58:400-405.

JoNES, T. A. 1998. Viewpoint: the present status and future prospects of squirreltail research. Journal of Range Management 51:326-331.

KnaPP, P. A. 1992. Secondary plant succession and vegetation recovery in two western Great Basin Desert ghost towns. Biological Conservation 60:81-89.

Knapp, P. A. 1996. Cheatgrass (Bromus tectorum $\mathrm{L}$ ) dominance in the Great Basin Desert. Global Environmental Change 6:37-52.

Krug, C. B., And R. M. Krug. 2007. Restoration of old fields in Renosterveld: a case study in a Mediterranean-type shrubland of South Africa. In: V. A. Cramer and R. J. Hobbs [EDS.]. Old fields: dynamics and restoration of abandoned farmland. Washington, DC, USA: Island Press. p. 265-285.

Leger, E. A. 2008. The adaptive value of remnant native plants in invaded communities: an example from the Great Basin. Ecological Applications 18:1226-1235.

Mack, R. N. 1981. Invasion of Bromus tectorum L. into western North America: an ecological chronicle. Agro-Ecosystems 7:145-165.

Mackown, C. T., T. A. Jones, D. A. Johnson, T. A. Monaco, and M. G. Redinbaugh. 2009. Nitrogen uptake by perennial and invasive annual grass seedlings: nitrogen form effects. Soil Science Society of America Journal 73:1864-1870.

McCune, B., and J. B. Grace. 2002. Analysis of ecological communities. Gleneden Beach, OR, USA: MjM Software Design. 300 p.

MorRIS, L. R. 2006. The ecological history of the City of Rocks National Reserve, part I: the human archive. Seattle, WA, USA: City of Rocks National Reserve, National Park Service Pacific Northwest Region. 114 p. Available at: http:// www.nps.gov/ciro/naturescience/index.htm. Accessed 25 July 2010.

Morris, L. R., And T. A. Monaco. 2010. Plowing up the past. Range 18:10-11.

Motzkin, G., D. Foster, A. Allen, J. Harrod, and R. Boone. 1996. Controlling site to evaluate history: vegetation patterns of a New England sand plain. Ecological Monographs 66:345-365. 
Motzkin, G., P. Wilson, D. R. Foster, and A. Arthur. 1999. Vegetation patterns in heterogeneous landscapes: the importance of history and environment. Journal of Vegetation Science 10:903-920.

Norton, J. B., T. A. Monaco, J. M. Norton, D. A. Johnson, and T. A. Jones. 2004. Soil morphology and organic matter dynamics under cheatgrass and sagebrushsteppe plant communities. Journal of Arid Environments 57:445-466.

[NRCS] Natural Resources Conservation Service. 1993. Utah ecological site descriptions. Available at: http://www.ut.nrcs.usda.gov/technical/technology/ range/mlra28a.html. Accessed 25 July 2010.

NRCS. 2006. Utah ecological site descriptions. Available at: http://www.ut.nrcs. usda.gov/technical/technology/range/ecosites.html. Accessed 25 July 2010.

NRCS. 2010. Official soil series descriptions. Available at: http://websoilsurvey. nrcs.usda.gov/app/. Accessed 25 July 2010.

Öster, M., K. Ask, S. A. O. Cousins, and 0. ERIKSson. 2009. Dispersal and establishment limitation reduces the potential for successful restoration of semi-natural grassland communities on former arable fields. Journal of Applied Ecology 46:1266-1274.

Pearse, C. K., and A. C. Hull. 1943. Some economic aspects of reseeding range lands. Journal of Forestry 41:346-358.

Pickett, S. T. A., S. L. Collins, and J. J. Armesto. 1987. Models, mechanisms, and pathways of succession. Botanical Review 53:335-371.

Piemeisel, R. L. 1938. Changes in weedy plant cover on cleared sagebrush land and their probable causes. Washington, DC, USA: US Department of Agriculture, Technical Bulletin No. 654. 44 p.

Reeves, F. B., D. Wagner, T. Moorman, and J. Kiel. 1979. The role of endomycorrhizae in revegetation practices in the semi-arid West. I. A comparison of incidence of mycorrhizae in severely disturbed vs. natural environments. American Journal of Botany 66:6-13.

Rickard, W. H., and R. H. Sauer. 1982. Self-revegetation of disturbed ground in deserts of Nevada and Washington. Northwest Science 56:41-47.

Samuel, M. J., and R. H. Hart. 1994. Sixty-one years of secondary succession on rangelands of the Wyoming high plains. Journal of Range Management 47:184-191.

SCofIELD, C. S. 1907. Dry farming in the Great Basin. Washington, DC, USA: US Department of Agriculture, Plant Industry Bureau Bulletin no. 103. 43 p.

SeAstedt, T. R., R. J. HobBs, and K. N. Suding. 2008. Management of novel ecosystems: are novel approaches required? Frontiers in Ecology and Environment 6:547-553.

Sheley, R. L., J. J. James, And E. C. BARD. 2009. Augmentative restoration: repairing damaged ecological processes during restoration of heterogeneous environments. Invasive Plant Science and Management 2:10-21.
Sheley, R. L., J. A. Mangold, and J. L. Anderson. 2006. Potential for successional theory to guide restoration of invasive-plant-dominated rangeland. Ecological Monographs 76:365-379.

Simmons, S. A., AND W. H. Rickard. 2002. Plant succession at the edges of two abandoned cultivated fields on the Arid Lands Ecology Reserve. Northwest Science 76:85-89.

Standish, R. J., V. A. Cramer, R. J. Hobbs, and H. T. Kobryn. 2006. Legacy of land-use evident in soils of Western Australia's wheatbelt. Plant and Soil 280:189-207.

Standish, R. J., V. A. Cramer, S. L. Wild, and R. J. Hobbs. 2007. Seed dispersal and recruitment limitation are barriers to native recolonization of old-fields in Western Australia. Journal of Applied Ecology 44:435-445.

Stewart, G. 1938. Revegetating man-made deserts. Journal of Forestry 36: 853-855.

Stewart, G., and A. C. Hull. 1949. Cheatgrass (Bromus tectorum L.)—an ecologic intruder in southern Idaho. Ecology 30:58-74.

Stylinski, C. D., AND E. B. Allen. 1999. Lack of native species recovery following severe exotic disturbance in southern Californian shrublands. Journal of Applied Ecology 36:544-554.

[USDA nRCS] US Department of Agriculture Natural Resources Conservation Service. 2010. The PLANTS database. Available at: http://plants.usda.gov. Accessed 3 September 2010.

WaLkeR, S. C., AND N. L. Shaw. 2005. Current and potential use of broadleaf herbs for reestablishing native communities. In: N. L. Shaw, M. Pellant, and S. B. Monsen [COMPILERS]. Proceedings: Sage-Grouse Habitat Restoration Symposium; 4-7 June 2001; Boise, ID. Fort Collins, CO, USA: US Department of Agriculture, Forest Service, RMRS-P-38. p. 56-61.

WatTS, M. J., AND C. L. Wambolt. 1996. Long-term recovery of Wyoming big sagebrush after four treatments. Journal of Environmental Management 46:35-102.

[WRCC] Western Regional Climate Center. 2008. Western Region Climate Center. Available at: www.wrcc.dri.edu. Accessed 25 July 2010.

Whisenant, S. G. 199. Repairing damaged wildlands: a process-orientated, landscape-scale approach. Cambridge, United Kingdom: Cambridge University Press. 312 p.

Wrobleski, D. W., and J. B. Kauffman. 2003. Initial effects of prescribed fire on morphology, abundance, and phenology of forbs in big sagebrush communities in southeastern Oregon. Restoration Ecology 11:82-90.

Young, J. A., C. D. Clements, and T. Jones. 2003. Germination of seeds of big and bottlebrush squirreltail. Journal of Range Management 56:277-281.

Young, J. A., And W. S. Longland. 1996. Impact of alien plants on Great Basin rangelands. Weed Technology 10:384-391. 